\title{
A Socio - Economic Study of Vegetable Growers Practicing under Badi in Balaghat District of Madhya Pradesh, India
}

\author{
Mohammad Imran Khan*, Kamleshwar Gautam, Sharad Bisen and S.B. Agrawal \\ College of Agriculture, Balaghat, M. P., Murjhad Farm Waraseoni (481331), India \\ *Corresponding author
}

\begin{tabular}{|c|}
\hline Keywords \\
\hline $\begin{array}{l}\text { Hand, Poor farmers, } \\
\text { Remunerative, Low } \\
\text { Productive, Small } \\
\text { land holdings }\end{array}$ \\
\hline Article Info \\
\hline $\begin{array}{l}\text { Accepted: } \\
22 \text { October } 2019 \\
\text { Available Online: } \\
10 \text { November } 2019\end{array}$ \\
\hline
\end{tabular}

\section{Introduction}

The land holding of farmers are gradually decreasing and as such the small holdings are becoming smaller day by day. The continuous increases in price of agricultural inputs are making agriculture enterprise less remunerative. Whatever so they are producing which is hardly sufficient to meet the food and other daily requirement of the family members. The small and marginal farmers have no sufficient scope to provide job opportunities to other, resulted in rural youths are migrating towards urban area in the search of job. On the other hand, poor farmers are not having sufficient sources of income to meet out their daily requirements. The Lalbarra block belonging to the Balaghat district having 
79 panchayats and most of the farmers of this block particularly the panchayats of Koppe, Chillod, and Lendejhari have low productive and small land holdings, resulted in low house hold income. The adverse climatic conditions and incidence of insect pest and diseases also create the economic insecurity due to failure of main field crop.

Keeping the above points in views a horticulture based module for Badi cultivation was incited in these villages based on the survey carried out by conducting face to face interviews of the farmers in the cluster of villages. It was come in to the knowledge that most of the farmers have no economic use of Badi (Area left surrounding their house). They have an area about $2000 \mathrm{~m}^{2}$ without any specific purpose. They simply use the area for keeping the animals for different purposes, feed and fodder for them. Only small portion are under taken to grow bottle guard, sponge guard, bitter guard, during in kharifonlyfor the purpose of vegetable for their own consumption. Hence, attempt has been made in this direction to assess and create awareness among the peoples by arranging training programmes about the utilization of space left surrounding their houses (Badi) for production of seasonal vegetables (Singh et al., 2018).

Training is and essential and vital to create confidence, motivation and enhance the efficiency of an individual. If we are going to trained the peoples it will be more effective if considered the need based aspects. (Agrawal et al., 2018)

\section{Materials and Methods}

The study was carried out in purposely selected villages Koppe, Chillod and Lendejhari under Farmer FIRST project, run under College of Agriculture, Balaghat, Murjhadfarm, Waraseoni, JNKVV Jabalpur (M.P.). Twenty farmers from each village
(Total 60 farmers) were selected for the study. The randomly selected farmers were provided seeds of different vegetable crops to cultivate in Badi (Space left the house) during rabi season, those who have sufficient water to irrigate the crops. The each selected farmer were also made available the plug trays, and vermi compost, for an area of $2000 \mathrm{~m}^{2}$ (Fig. $1)$.

Before launching of the project "Farmer FIRST" a bench mark survey of adopted villages was done based on agro - ecological situations and assets with the farmers in terms of irrigation facilities, transportation facilities along with roads (Table 2). The distance from the nearby market to selected villages which were pooled in three clusters (Table 1).

The awareness cum skill development Programme (Table 3) was initiated in these villages in order to popularize the techniques among the farmers for utilizing space left surrounding the houses by growing of seasonal vegetables through trainings with respect to production technologies of seasonal vegetables.

Table 3: Number of programmes organized for creating awareness come skill development numbers of respondents participated in the programme during $2016-17$ to 2018 - 19

The primary data collection was done by face to face interviews of Gram Panchayat Sarpanch, Secretory and progressive farmers, whereas the secondary data were collected from base line survey of the project. (Anonymous 2016)

\section{Results and Discussion}

The profile of the respondents in relation to their age, education level, land holdings and occupation are given in Table 4. It is clear from the data that out of 60 most of the 
respondent (46.00 respondents) belongs to meddle age group ( $76.66 \%$ ) followed by $(13.33 \%)$ and $(10.00 \%)$ under old and young age group, respectively. Out of the total respondents $(51.67 \%)$ has passed higher secondary and above level of formal education followed by $(26.67 \%)$ middle and $(18.33 \%)$ primary level of education. Whereas only 02 $(3.33 \%)$ were illiterate.Majority of respondents were small $(51.67 \%)$ and marginal farmers $(40.00 \%)$ and few of them $(8.33 \%)$ respondents possessed medium size of land holding.The majority of respondents $(41.67 \%)$ were engaged in agricultural work on their own farm either alone or association with agricultural labors. ( $21.67 \%$ ) respondents were engaged in other occupation with agricultural work. None of the participants doing the govt. regular or private job, they depended on the agricultural work and some allied enterprises. ( Singh et al., 2017) found most of the vegetable growers were middle aged, have small land holdings and engaged in agricultural work as occupation.

While studying the communicational attributes in terms of exposure to mass media and contact with the development agencies, it was noted that the highest number 26 (43.33 $\%$ )had high mass media exposure followed by medium 19 number $(31.67 \%)$ while 15 number $(25.00 \%)$ had lower exposer to mass media. Majority of the vegetable growers 25 $(41.67 \%)$ and $19(36.66 \%)$ were classified into high and medium level of contact with development agencies, respectively. More over remaining $(21.67 \%)$ vegetable growers had low level of contact with development agencies (Table 5).

Table.1 Details of villages selected under clusters.

\begin{tabular}{|c|c|c|c|}
\hline S. No. & Name of cluster & Name of village & $\begin{array}{c}\text { Distance from nearby } \\
\text { waraseoni market }\end{array}$ \\
\hline $\mathbf{1}$ & Koppe & Koppe, Budhatola, Amraitola, NarbodTola, & 6 \\
\hline $\mathbf{2 .}$ & Chillod & Chillod, Mararitola, Raghotola, School tola & 9 \\
\hline $\mathbf{3 .}$ & Lendejhari & Lendejhari,Basti & 10 \\
\hline
\end{tabular}

Table.2 Agro - ecological situation of villages under clusters

\begin{tabular}{|c|c|c|c|c|c|c|c|}
\hline \multirow[t]{2}{*}{ Village } & \multirow[t]{2}{*}{ Topography } & \multirow[t]{2}{*}{$\begin{array}{l}\text { Soil } \\
\text { type }\end{array}$} & \multirow[t]{2}{*}{ Cropping System } & \multicolumn{2}{|c|}{$\begin{array}{l}\text { Crops use to } \\
\text { grow }\end{array}$} & \multirow[t]{2}{*}{$\begin{array}{l}\text { Irrigation } \\
\text { sources }\end{array}$} & \multirow[t]{2}{*}{$\begin{array}{l}\text { Land } \\
\text { holding }\end{array}$} \\
\hline & & & & Kharif & Rabi & & \\
\hline Koppe & $\begin{array}{l}\text { Undulated, } \\
\text { sloppy, bunded } \\
\text { fields }\end{array}$ & Loamy & $\begin{array}{c}\text { Rice - Fallow, } \\
\text { Rice }(\mathrm{K}) \text { - Rice (S) }\end{array}$ & Rice & Fallow & $\begin{array}{c}\text { Canal, } \\
\text { Open well, }\end{array}$ & $\begin{array}{l}\text { Marginal } \\
\& \text { small }\end{array}$ \\
\hline Chillod & $\begin{array}{l}\text { Sloppy, eroded } \\
\text { soils, bunded } \\
\text { fields }\end{array}$ & $\begin{array}{l}\text { Silty, } \\
\text { clay } \\
\text { loam }\end{array}$ & $\begin{array}{c}\text { Rice - Fallow } \\
\text { Rice - Chick pea }\end{array}$ & $\begin{array}{l}\text { Rice } \\
\text { Pigeon } \\
\text { pea }\end{array}$ & $\begin{array}{c}\text { Fallow, } \\
\text { Chick } \\
\text { pea }\end{array}$ & $\begin{array}{l}\text { Canal, Bore } \\
\text { well, Tank }\end{array}$ & $\begin{array}{l}\text { Small \& } \\
\text { medium }\end{array}$ \\
\hline Lendejhari & $\begin{array}{c}\text { Sloppy, and } \\
\text { bunded fields }\end{array}$ & $\begin{array}{l}\text { Sandy } \\
\text { loam }\end{array}$ & $\begin{array}{c}\text { Rice - Linseed, } \\
\text { Rice - Wheat, } \\
\text { Rice }(\mathrm{K}) \text { - Rice }(\mathrm{S})\end{array}$ & Rice & $\begin{array}{l}\text { Wheat, } \\
\text { Linseed }\end{array}$ & $\begin{array}{l}\text { Canal, water } \\
\text { tank, and } \\
\text { open well }\end{array}$ & $\begin{array}{l}\text { Small \& } \\
\text { medium }\end{array}$ \\
\hline
\end{tabular}

$\mathrm{K}=$ Kharif, $\mathrm{S}=$ Summer 
Table.3

\begin{tabular}{|c|c|c|c|c|}
\hline Year & $\begin{array}{c}\text { No of programmes } \\
\text { organized }\end{array}$ & $\begin{array}{c}\text { Duration } \\
\text { (days) }\end{array}$ & No of participants & No of villages \\
\hline $\mathbf{2 0 1 6}-\mathbf{1 7}$ & 3 & 2 & 174 & 10 \\
\hline $\mathbf{2 0 1 7}-\mathbf{1 8}$ & 3 & 2 & 180 & 10 \\
\hline $\mathbf{2 0 1 8}-\mathbf{1 9}$ & 2 & 2 & 168 & 10 \\
\hline Total & $\mathbf{8}$ & $\mathbf{6}$ & $\mathbf{5 2 2}$ & $\mathbf{3 0}$ \\
\hline
\end{tabular}

Table.4 Distribution of the vegetable growers according to their age, education level land holding and occupation

\begin{tabular}{|c|c|c|c|}
\hline S. No. & Categories & Number & Percentage \\
\hline \multirow[t]{4}{*}{1.} & Age of the respondents & & \\
\hline & Young $(18-25$ years $)$ & 6 & 10.00 \\
\hline & Middle $(26-50$ years $)$ & 46 & 76.66 \\
\hline & Old (above 50 years) & 8 & 13.33 \\
\hline \multirow[t]{5}{*}{2.} & Education level & & \\
\hline & Illiterate & 2 & 3.33 \\
\hline & Primary passed & 11 & 18.33 \\
\hline & Middle passed & 16 & 26.67 \\
\hline & High school passed and above & 31 & 51.67 \\
\hline \multirow[t]{5}{*}{3} & Size of land holdings & & \\
\hline & Marginal (Up to 1 ha) & 24 & 40.00 \\
\hline & Small (1.01 to $2 \mathrm{ha})$ & 31 & 51.67 \\
\hline & Medium (2.01 to 5 ha) & 5 & 8.33 \\
\hline & Large (Above 5 ha) & 0 & 0 \\
\hline \multirow[t]{5}{*}{4.} & Occupation & & \\
\hline & Agriculture & 25 & 41.67 \\
\hline & Agriculture + Agriculture Labour & 22 & 36.67 \\
\hline & Agriculture + other occupation & 13 & 21.67 \\
\hline & Agriculture + Regular / private service & 0 & 0 \\
\hline
\end{tabular}

Table.5 Distribution of the vegetable growers according to their communicational attributes

\begin{tabular}{|c|c|c|c|}
\hline S. No. & Category & Number & Percentage \\
\hline $\mathbf{1 .}$ & Mass media exposer & & \\
\hline & Low (up to 7) & 15 & 25.00 \\
& Medium (8 - 11) & 19 & 31.67 \\
\hline $\mathbf{2 .}$ & High (above 11) & & 43.33 \\
\hline & Contact with development agencies & 13 & 21.67 \\
& Low (Up to 6) & 22 & 36.66 \\
& Medium (7 - 10) & 25 & 41.67 \\
\hline
\end{tabular}


Table.6 Production potential of rabi vegetables under badi

\begin{tabular}{|c|c|c|c|c|}
\hline S. No. & Name of crop & Area $\left.\mathbf{( m}^{\mathbf{2}}\right)$ & Average production in (kg) & Duration (Days) \\
\hline $\mathbf{1}$ & Okara & 400 & 360 & 87 \\
\hline $\mathbf{2}$ & Bottle Guard & 100 & 160 & 88 \\
\hline $\mathbf{3}$ & Chilli & 300 & 150 & 140 \\
\hline $\mathbf{4}$ & Brinjal & 400 & 1640 & 125 \\
\hline $\mathbf{5}$ & Tomato & 400 & 1360 & 125 \\
\hline $\mathbf{6}$ & Cabbage & 400 & 1300 & 115 \\
\hline & Total & $\mathbf{2 0 0 0}$ & $\mathbf{4 9 7 0}$ & \\
\hline
\end{tabular}

Table.7 Income generation (Rs.) with the cultivation of vegetables from $1 / 5^{\text {th }}$ ha area $\left(2000 \mathrm{~m}^{2}\right)$ of badi

\begin{tabular}{|c|c|c|c|c|c|c|}
\hline $\begin{array}{c}\text { S. } \\
\text { No. }\end{array}$ & Name of crop & $\begin{array}{c}\text { Area } \\
\left(\mathbf{m}^{2}\right)\end{array}$ & $\begin{array}{c}\text { Cost of } \\
\text { cultivation } \\
(\text { Rs. })\end{array}$ & $\begin{array}{c}\text { Gross } \\
\text { return } \\
(\mathbf{R s .})\end{array}$ & $\begin{array}{c}\text { Net } \\
\text { return } \\
(\text { Rs. })\end{array}$ & $\begin{array}{c}\text { Net } \\
\text { Income } / \\
\text { Day }\end{array}$ \\
\hline $\mathbf{1}$ & Okara & 400 & 2800 & 7200 & 4400 & 51 \\
\hline $\mathbf{2}$ & Bottle Guard & 100 & 650 & 1600 & 950 & 11 \\
\hline $\mathbf{3}$ & Chilli & 300 & 1150 & 2250 & 1100 & 8 \\
\hline $\mathbf{4}$ & Brinjal & 400 & 2200 & 11480 & 9280 & 74 \\
\hline $\mathbf{5}$ & Tomato & 400 & 2680 & 10880 & 8200 & 66 \\
\hline $\mathbf{6}$ & Cabbage & 400 & 2400 & 4550 & 2150 & 19 \\
\hline & Total & $\mathbf{2 0 0 0}$ & $\mathbf{1 1 8 8 0}$ & $\mathbf{3 7 9 6 0}$ & $\mathbf{2 6 0 8 0}$ & $\mathbf{2 2 9}$ \\
\hline
\end{tabular}

Fig.1 Geo - graphical location of selected villages

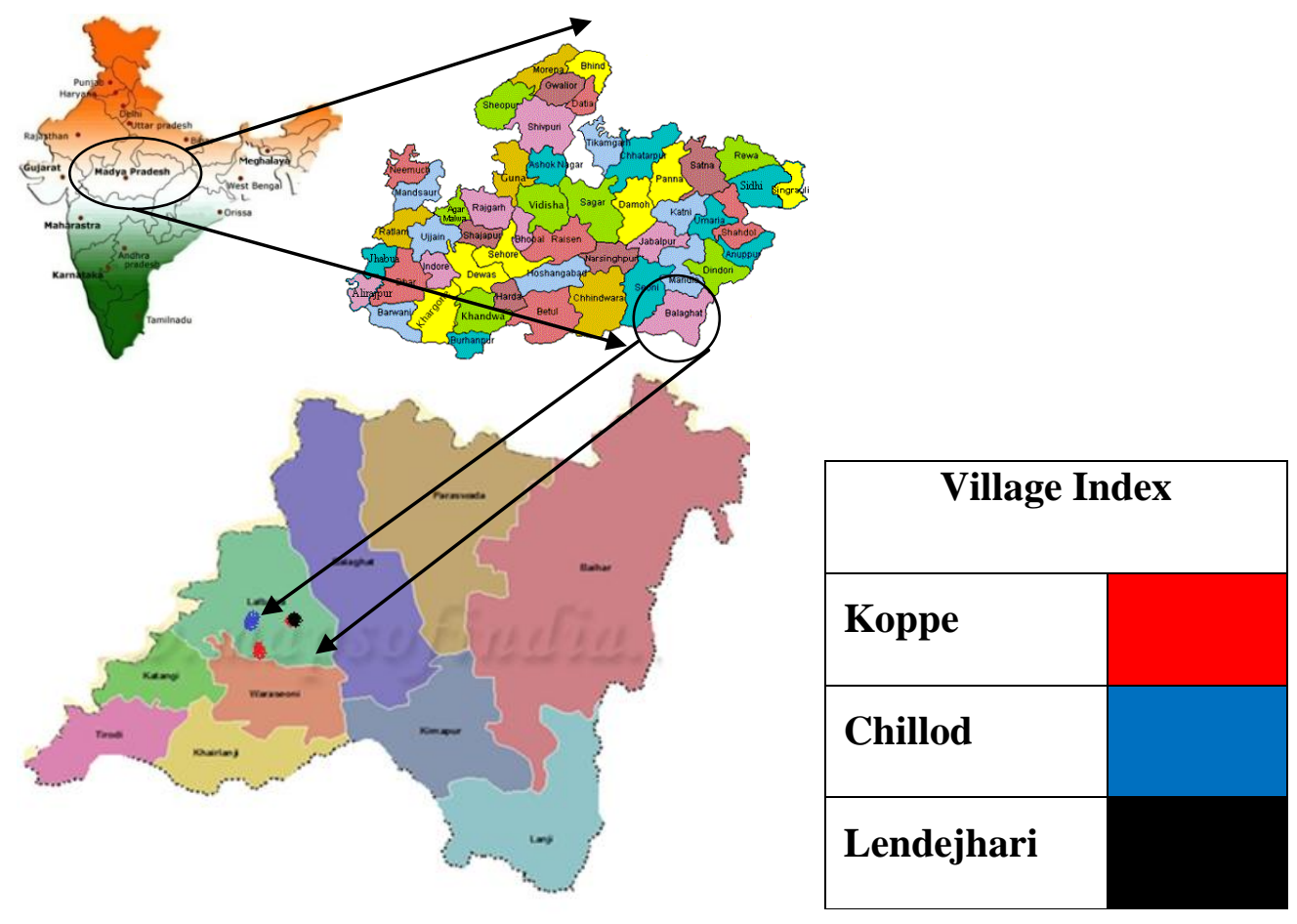


A total of 60 respondents were provided skill development training and inputs for growing of vegetables round the year for the purpose of sale and family consumption. Each and every respondent were use the space about $2000 \mathrm{~m}^{2}$ for the vegetable cultivation in Badi (Table 6). Result shows that on an average $4970 \mathrm{~kg}$ of different vegetables were produced by the respondents in $2000 \mathrm{~m}^{2}$ area under badi within 140 days. Further analysis of cost of cultivation and return are given in Table 7. It is clear from the data that Rs 11880 is the cost of cultivation for the six vegetable crops grown on area of $2000 \mathrm{~m}^{2}$. However, cost of cultivation is different for different crops and allotted area. Farmers get maximum net return of Rs. 9280 from brinjal, closely followed by Rs. 8200 from tomato within a 125 days.However, the bottle guard and chili found less remunerative. From the result it can be concluded that on an average a small farmer may earn at least Rs. 229 per day from their back yard gardening with the cultivation of seasonable vegetables. Similar options were reported by Singh et al., (2018) and stated that farmers can grow more remunerative crops like vegetable instead of wheat and paddy and may earn more profit within a short period.

It can be concluded from the above findings that the majority of the vegetable growers were middle aged, having high school and above level of education and possessed small to marginal size of land holdings. Most of the vegetable growers had high level of mass media exposer and contact with the development agencies and get the technical knowledge. On the bases of average production and cost involved it, found that the cultivation of six different vegetables, a family having an area of about $2000 \mathrm{~m}^{2}$ may earn Rs. 26080 within 140 days. Which mean it gave about Rs. 229 per day, in addition to their routine work.

\section{References}

Agrawal, S. B.; D. P. Sharma; B.S. Kirar; AtulShrivastava and Archna Pandey (2018). Impact analysis of a Training Programme Preparation and use of Vermicompost in crop Production. Journal of Pharma Cogoncy and Phytochemistry 7(5): $3144-3146$.

Anonymous (2016) Agro ecological Survey report of Lalbarra block Balaghat, College of Agriculture Balaghat. PP. 8.

Singh,Dan; D. K. Singh; R. N. Yadav; Satya Prakash and Kumari Shanti (2017). Study on Personal Socio - Agro Economic, Psychological and Communicational Characteristics of the Vegetable Growers in Western Uttar Pradesh, India. International Journal of Current Microbiology and Applied Science. 6(7): 2255 - 2262.

Singh, Shrawan; Brij Bihari Sharma and B. S. Tomar(2018) Gardning Vegetables for health and wealth. Indian Horticulture. 63(1):41 - 44 .

Singh, V. K; S. K. Singh, K.C. Shukla and Amiraj Dubey (2018) In Bundelkhand; Profit maximization with horticulture crops. Indian Horticulture 63(1): 31.

\section{How to cite this article:}

Mohammad Imran Khan, Kamleshwar Gautam, Sharad Bisen and Agrawal, S.B. 2019. A Socio - Economic Study of Vegetable Growers Practicing under Badi in Balaghat District of Madhya Pradesh, India. Int.J.Curr.Microbiol.App.Sci. 8(11): 2363-2368. doi: https://doi.org/10.20546/ijcmas.2019.811.273 